\title{
Communication
}

[Comunicação]

\section{Thyroid parafollicular cell hyperplasia and carcinoma in a sheep with enzootic calcinosis due to Nierembergia rivularis poisoning}

\author{
[Hiperplasia e carcinoma de células parafoliculares da tireóide em ovino com calcinose \\ enzoótica associada a intoxicação por Nierembergia rivularis]
}

\author{
M. Machado ${ }^{1}$, M. Preliasco ${ }^{2}$, C.O. Schild 1 , R.A. Costa ${ }^{1}$,
} A. Balserini ${ }^{3}$, F. Giannitti $^{4}$, F. Riet-Correa ${ }^{4}$

\begin{abstract}
${ }^{1}$ Aluno de pós-graduação - Instituto Nacional de Investigación Agropecuaria - Tacuarembó, Uruguay ${ }^{2}$ División de Laboratorios Veterinarios - Ministerio de Ganadería, Agricultura y Pesca - Montevideo, Uruguay

${ }^{3}$ División Sanidad Animal - Ministerio de Ganadería, Agricultura y Pesca - Tacuarembó, Uruguay

${ }^{4}$ Instituto Nacional de Investigación Agropecuaria - Plataforma de Salud Animal - Colonia, Uruguay
\end{abstract}

Enzootic calcinosis (EC) in ruminants is usually caused by the ingestion of calcinogenic plants, including Solanum glaucophyllum (syn. Solanum malacoxylon) (Mello, 2003), Nierembergia veitchii (Riet-Correa et al., 1987) and Nierembergia rivularis (syn. Nierembergia repens) in South America (Santos et al., 2012), Cestrum diurnum in North America, Trisetum flavescens in Europe, and Solanum torvum in Oceania (Mello, 2003). S. glaucophyllum and $C$. diurnum contain 1-alpha, 25- dihydroxyvitamin $\mathrm{D}_{3}\left[1 \alpha, 25(\mathrm{OH})_{2} \mathrm{D}_{3}\right]$ (calcitriol) (Wasserman et al., 1976; Mello, 2003). Although the chemical structure of the toxic compound in Nierembergia spp. is unknown, $N$. veitchii possesses a similar in vivo biological activity to calcitriol.

Poisoning by these plants alters calcium and phosphorous metabolism, inducing hypercalcemia and hyperphosphatemia, soft tissue mineralization (calcinosis), hyperplasia of the thyroid parafollicular $(\mathrm{C})$ cells, atrophy of the parathyroid glands, and osteopetrosis (RietCorrea et al., 1987). C cell hyperplasia in cases of EC is induced by hypercalcemia, which is the principal stimulus for the production of calcitonin, a hormone produced by these cells that lowers plasma calcium levels (Riet-Correa et al., 1987). Although parafollicular cell hyperplasia is a preneoplastic lesion induced by hypercalcemia that can progress to neoplasia (Rosol and Grone, 2015), the malignant neoplastic transformation of parafollicular cells has not been recorded in cases of EC. We present the pathological and immunohistochemical findings in a case of thyroid C-cell hyperplasia and carcinoma in a sheep with enzootic calcinosis caused by $N$. rivularis.

In February 2016, an outbreak of EC was diagnosed on a farm located on an island in Rincon del Bonete Lake in the Department of Durazno, Uruguay. Eight of 110 sheep died after showing chronic weight loss, weakness, stiffness, and exercise intolerance over a period of 2-4 months. Nierembergia sp. was found in large quantities on the shores of the lake. A voucher specimen of the plant, identified as $N$. rivularis Miers (syn. N. repens Ruiz \& Pav) (Cabrera, 1979), was deposited with access number MVFA 34988 at the herbarium "Ing. Agr. Bernardo Rosengurtt", at the Agronomy Faculty of the Republic University in Montevideo, Uruguay.

A 4-year-old sheep that died in this flock was necropsied. Postmortem examination revealed severe cachexia. Major arteries, including the thoracic and abdominal aorta, the internal carotid and the coronary arteries, had diffusely rigid walls with a marked loss of elasticity and were variably thickened by extensive, irregular, roughly surfaced, firm-to-hard, white, crepitant, intramural plaques and nodules that narrowed their lumens. Similar deposits expanded to the

Recebido em 27 de novembro de 2019

Aceito em 9 de março de 2020

E-mail: mizaelmachado@hotmail.com 
bicuspid valve, including the chordae tendineae, and the aortic semilunar valves. Mineralized deposits were also found in the pulmonary parenchyma and bronchi, and the caudodorsal aspects of the caudal lung lobes failed to collapse. Extending diffusely from the corticomedullary junction to the medullary side of the renal parenchyma in both kidneys, there was a fairly well-demarcated band in which the renal parenchyma had myriad pinpoint, equidistant, white, chalky mineralized foci, often arranged in linear arrays. Additionally, multiple, coalescing, irregular, white, homogeneous nodules, up to 3$10 \mathrm{~mm}$ in size, with indistinct borders, expanded to the thyroid gland bilaterally (Figure 1).

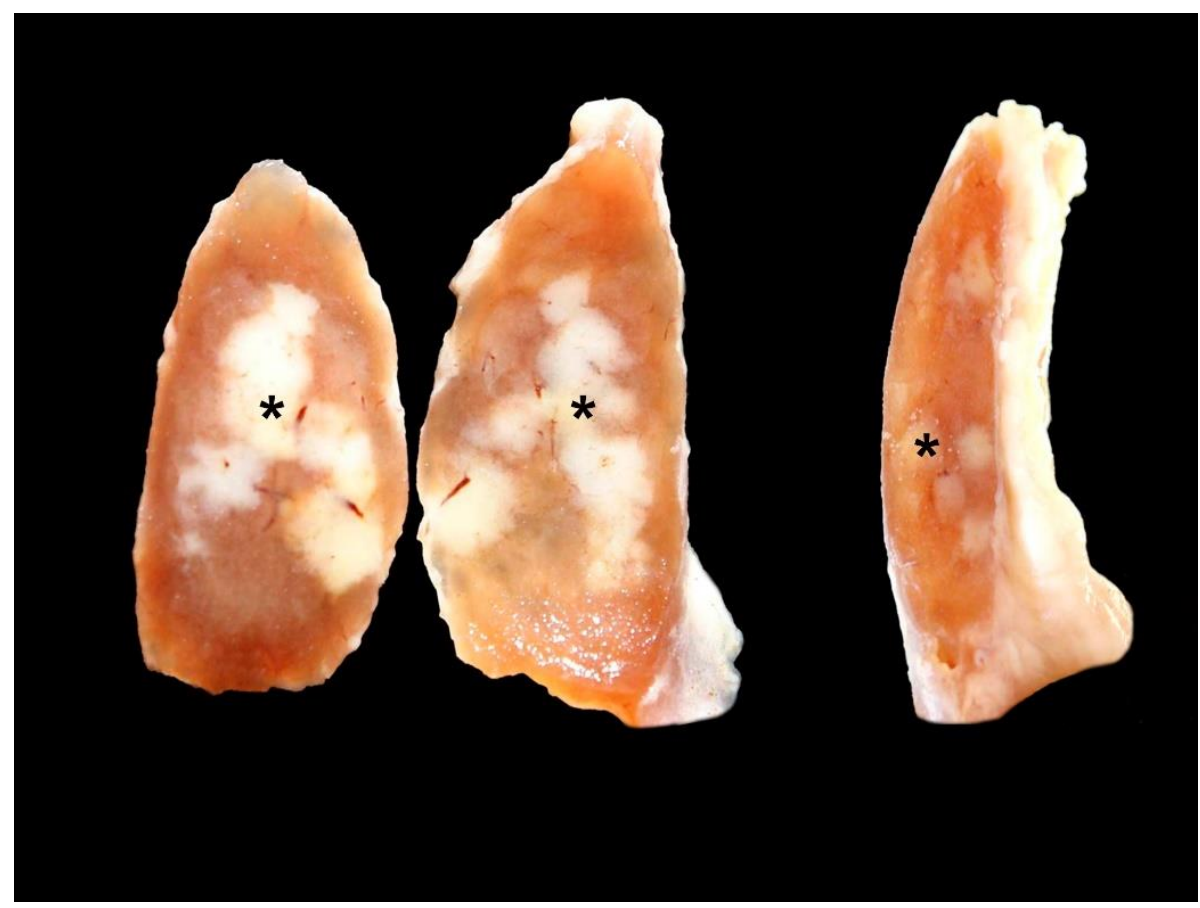

Figure 1. Sheep poisoned by Nierembergia rivularis. Thyroid gland. Parafollicular cell hyperplasia and carcinoma. Multiple, coalescing, irregular, white nodules with variable distinct borders cover the parenchyma $(*)$.

Histologic examination revealed mineralization of the soft tissues, which was particularly severe in the tunica media of the aorta and coronary arterioles, alveolar septa of the lungs, and renal tubules and arterioles. In the affected arteries and arterioles, medial mineralization was often accompanied by intimal hyperplasia. The mineral nature of the deposits in the aorta, lungs and kidneys was confirmed by Von Kossa staining.

Additionally, the thyroid gland showed extensive disruption of the histoarchitecture by multinodular, non-encapsulated, moderate-tohighly cellular masses, composed of proliferating epithelial cells arranged in solid nests, nodules, and packets, supported by a fine fibrovascular stroma (Figure 2A). The cells were round to polygonal in shape, with moderate amounts of finely granular eosinophilic cytoplasm, indistinct cell borders, round to oval central or paracentral nuclei with coarse chromatin, and 1-2 magenta nucleoli. Anisocytosis and anisokaryosis were moderate. In areas of high cellularity, some cells were spindle-shaped, and occasional cells showed karyomegaly, vesicular chromatin, and/or nuclear membrane indentations. Occasional neoplastic cells within nodules had a shrunken hypereosinophilic cytoplasm with nuclear pyknosis or karyorrhexis (Figure 2B). 


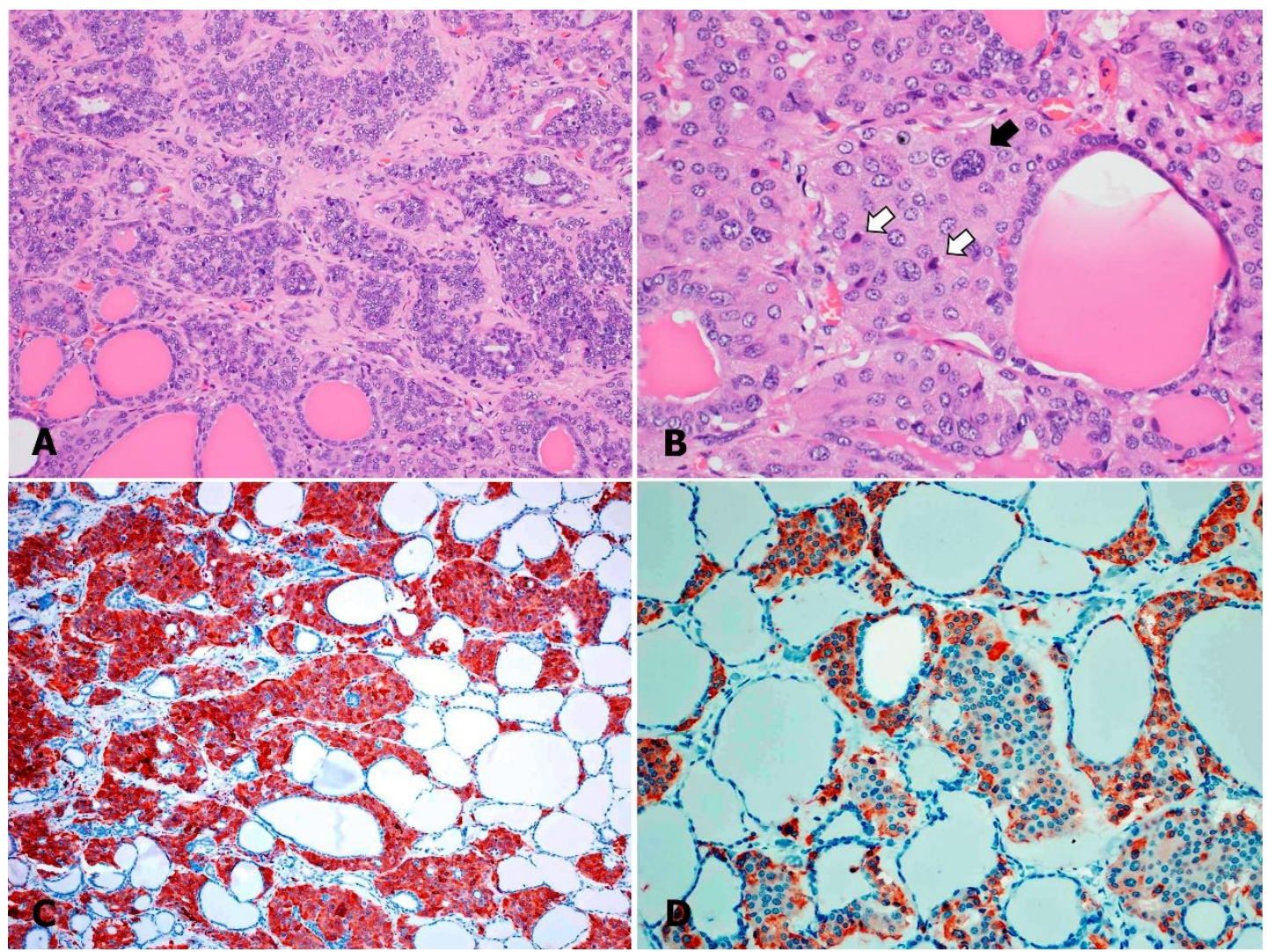

Figure 2. Sheep poisoned by Nierembergia rivularis. Thyroid gland. Parafollicular cell carcinoma. A. Section of thyroid disrupted by a partially delimited multilobular, expansive and unencapsulated mass, composed of cells arranged in nests and packets, supported by a minimal amount of fibrovascular stroma; H\&E. 200x. B. Moderate anisocytosis and anisokaryosis, with karyomegaly (black arrow) and apoptotic cells (white arrows); H\&E, 400x. C. Neuron-specific enolase immunohistochemistry. Diffuse, strong, granular, cytoplasmic immunoreactivity in neoplastic cells; 200x. D. Calcitonin immunohistochemistry. Granular cytoplasmic immunoreactivity is evident in some neoplastic parafollicular cells; 200x.

In some areas, the proliferating cells compressed and partially or completely occluded the thyroid follicles and occasionally disrupted the basement membrane and infiltrated the interstitium, entrapping pre-existing colloid-filled thyroid follicles, which were sometimes lined with hyperplastic thyroid epithelium. Multifocally in these areas, the infiltrating cells were separated by eosinophilic fibrillary collagenous material that was highlighted by Gomori trichrome staining. Occasionally, neoplastic cells surrounded a homogeneous, amorphous, lightly eosinophilic, extracellular material that was negative for Congo red stain for amyloid. There was less than 1 mitotic figure per 10, 400x fields. In the betterpreserved areas of the thyroid gland, distant to large masses, there was multifocal widespread nodular and diffuse parafollicular cell hyperplasia.
Immunohistochemistry against calcitonin, calcitonin gene-related peptide (CGRP), neuronspecific enolase (NSE), chromogranin A (CgA), and proliferating cell nuclear antigen (PCNA) was performed by following validated procedures at the University of Minnesota Veterinary Diagnostic Laboratory. The proliferating epithelial cells were positive for NSE (Figure 2C), calcitonin (Figure 2D), and CGRP and negative for $\mathrm{CgA}$, an immunophenotype that is consistent with parafollicular cells (Okada et al., 1991b). Interestingly, while most proliferating cells showed strong diffuse granular cytoplasmic immunoreactivity against calcitonin, in other cells, the immunoreactivity was minimal (faint) or even nondetectable, suggesting cellular undifferentiation, which also supports a diagnosis of malignancy (Wasserman et al., 1976). The immunoreactivity against NSE was uniformly 
strong, diffuse, cytoplasmic, and granular in the vast majority of neoplastic cells. Additionally, a large proportion of proliferating parafollicular cells were immunoreactive to PCNA, with diffuse granular nuclear reactivity.

Clinical, gross and histopathological findings in this sheep were all consistent with EC (RietCorrea et al., 1987). The main lesion caused by $\mathrm{EC}$ is the mineralization of the tunica media of the arteries. Gene expression modulated by the action of $1 \alpha, 25(\mathrm{OH})_{2} \mathrm{D}_{3}$ and derived glycosides is known to promote smooth muscle cell differentiation and bone matrix protein synthesis. Modified smooth muscle cells produce and secrete components of the extracellular matrix with a high affinity for calcium precipitation and consequent mineralization (Barros et al., 2006).

The sheep flock where this case originated had been grazing for 5 to 6 months, from late spring to early autumn, in a natural grassland highly invaded by $N$. rivularis. Similar to other calcinogenic plants, Nierembergia spp. poisoning induces hypercalcemia and hyperphosphatemia, which in turn result in thyroid parafollicular cell hyperplasia, parathyroid gland atrophy and osteopetrosis (Rosol and Grone, 2015). Hypercalcemia is primarily mediated by the induction of calcium-binding protein synthesis in the intestinal tract, which leads to increased calcium and phosphorus absorption (Riet-Correa et al., 1987; Mello, 2003).

The increased calcium concentration in the plasma and extracellular fluids is the main stimulus for the secretion of calcitonin, a calciumregulating hormone secreted by thyroid parafollicular cells that reduces plasma calcium levels (Rosol and Grone, 2015). Hyperplasia of the parafollicular cells is a response to chronic hypercalcemia (Okada et al., 1991b) and can occur due to the ingestion of calcinogenic plants, long-term intake of excess calcium (Rosol and Grone, 2015), or, more rarely, as a manifestation of paraneoplastic hypercalcemia (hypercalcemia of malignancy) (Okada et al., 1991a; Rosol and Grone, 2015). As a preneoplastic lesion, parafollicular cell hyperplasia induced by chronic hypercalcemia can progress to adenoma and carcinoma (Rosol and Grone, 2015).

In ruminants, parafollicular cell hyperplasia has been described in spontaneous and experimental cases of EC induced by plants, including $N$. veitchii (Riet-Correa et al., 1987), C. diurnum and S. glaucophyllum (Mello, 2003). Parafollicular cell adenoma has been described in one sheep with calcinosis of unknown cause (Neumann and Klopfer, 1975).

In a study, $30 \%$ of bulls fed high-calcium diets developed parafollicular cell hyperplasia or neoplasia (Rosol and Grone, 2015). Parafollicular cell hyperplasia and carcinoma have been described in sheep with hypercalcemia of malignancy associated with bovine leukemia virus-induced lymphosarcoma (Okada et al., 1991a). The malignant differentiation of thyroid C cells may result from a preneoplastic change in response to chronic hypercalcemia (Wasserman et al., 1976). The histological pattern of hyperplasia and adenoma is not particularly distinct, which makes the diagnosis difficult. However, the characteristics of malignancy present in carcinomas, such as invasive and disorganized cell proliferation, cellular pleomorphism and mitotic figures, facilitate the diagnosis (Wasserman et al., 1976).

Although there was a spectrum of lesions that varied from hyperplasia to neoplasia in different sections and within sections in this thyroid gland, we based the diagnosis of parafollicular cell carcinoma on the following criteria: a lack of encapsulation, presence of highly cellular areas, moderate cellular pleomorphism, anisocytosis and anisokaryosis, neoplastic cells showing karyomegaly and nuclear atypia, and disruption of the follicular basement membrane with the intrathyroidal infiltration of neoplastic cells and fibroplasia. The histologic diagnosis was coupled with that of the immunohistochemistry.

In this case, we suggest that chronic hypercalcemia induced by $N$. rivularis poisoning may have been a predisposing factor leading to parafollicular cell hyperplasia and eventual neoplastic transformation, as described in other conditions associated with chronic hypercalcemia in sheep (Okada et al., 1991a).

\section{ACKNOWLEDGMENTS}

We thank Yisell Perdomo from the "Instituto Nacional de Investigación Agropecuaria" and Jan Shivers from the University of Minnesota Veterinary Diagnostic Laboratory for technical 
assistance with the histology and immunohistochemistry. This work was funded by grant PL_015 N-15156 from the Instituto Nacional de Investigación Agropecuaria (INIA), Uruguay. A postgraduate scholarship was provided by Instituto Nacional de Investigación Agropecuaria (INIA), Uruguay.

Keywords: calcinogenic plants, endocrine system, sheep diseases, toxic plants, neoplasia

\section{RESUMO}

Calcinose enzoótica, causada por Nierembergia rivularis, no Uruguai, e Nierembergia veitchii, no Brasil, é uma doença caracterizada por mineralização de tecidos moles, hiperplasia das células parafoliculares da tireoide e elevação nos níveis de cálcio e fósforo. Descreve-se um caso de hiperplasia e carcinoma de células parafoliculares bilateral em um ovino de quatro anos, com calcinose enzoótica associada à intoxicação por Nierembergia rivularis. O diagnóstico histológico de hiperplasia e carcinoma de células parafoliculares é suportado pelas marcações imuno-histoquímicas positivas para calcitonina, peptídeo relacionado ao gene da calcitonina e enolase neurônio específica. Como a hiperplasia de células parafoliculares é uma lesão pré-neoplásica induzida por hipercalcemia, sugere-se que a hipercalcemia crônica causada pela intoxicação por $N$. rivularis pode ter induzido hiperplasia de células parafoliculares seguida de transformação em carcinoma, neste caso. Os efeitos carcinogênicos das plantas calcinogênicas no sistema endócrino devem ser melhor explorados.

Palavras-chave: doença de ovinos, neoplasia, plantas calcinogênicas, plantas tóxicas, sistema endócrino

\section{REFERENCES}

BARROS, S.S.; REEVES, W.C.; HARDY, J.L. Macrophages and giant cell proliferation associated with bone protein synthesis and calcification in the trachea and bronchi of rabbits intoxicated with Solanum glaucophyllum. Vet. Pathol., v.43, p.494-499, 2006.

CABRERA, A.L. Solanaceae. In: BURKART, A. (Ed.). Flora ilustrada de Entre Ríos. Buenos Aires: INTA, 1979. p.346-452.

MELLO, J.R.B. Calcinosis-calcinogenic plants. Toxicon, v.41, p.1-12, 2003.

NEUMANN, F.; KLOPFER, U. Calcinosis in sheep associated with $\mathrm{C}$ cell adenoma of the thyroid. Vet. Med. Small Anim. Clin., v.70, p.1209-1212, 1975.

OKADA, H.; FUJIMOTO, Y.; OHSHIMA, K.; MATSUKAWA, K.C. Cell hyperplasia and carcinoma developing in sheep with experimentally-induced lymphosarcoma. $J$. Comp. Pathol., v.105, p.313-322, 1991 a.
OKADA, H.; TOYOTA, N.; HARIMAYA, Y.; MATSUKAWA, K. Immunohistochemical alterations of $\mathrm{C}$ cells in sheep treated with vitamin D. J. Comp. Pathol., v.105, p.263-270, 1991 b.

RIET-CORREA, F.; SCHILD, A.L.; MENDEZ, M.C.; WASSERMAN, R. et al. Enzootic calcinosis in sheep caused by the ingestion of Nierembergia veitchii (Solanaceae). Pesqui. Vet. Bras., v.7, p.85-95,1987.

ROSOL, T.J.; GRÖNE, A. Endocrine glands. In: MAXIE, M.G. (Ed.). Jubb, Kennedy and Palmer's, pathology of domestic animals. Philadelphia: Elsevier, 2015. p.332-336.

SANTOS, C.G.; PEREIRA, R.; ETCHEBERRY, $\mathrm{G}$. et al. Enzootic calcinosis caused by Nierembergia rivularis in sheep. J. Vet. Diagn. Invest., v.24, p.423-426, 2012.

WASSERMAN, R.H.; HENION, J.D.; HAUSSLER, M.R.; MCCAIN, T.A. Calcinogenic factor in Solanum malacoxylon: evidence that it is 1,25-dihydroxyvitamin D3glycoside. Science, v.19, p.853-855, 1976. 